\title{
PENGEMBANGAN KOMODITAS POTENSIAL DAN PERANANYA TERHADAP PERLUASAN KESEMPATAN KERJA DAN PENANGGULANGAN KEMISKINAN DI KABUPATEN SELUMA
}

\author{
Rina Trisna Yanti \\ Program Studi Keuangan dan Perbankan \\ Fakultas Ekonomi Universitas Dehasen Bengkulu
}

\begin{abstract}
ABSTRAK
Rina Trisna Yanti; Tujuan penelitian ini adalah Untuk mengetahui peran komoditas potensial terhadap Perluasan Kesempatan Kerja di Kabupaten Seluma dan Untuk mengetahui peran komoditas potensial terhadap Pengentasan Kemiskinan di Kabupaten Seluma. Jenis penelitian ini adalah penelitian deskriptif kualitatif. Penelitian ini tidak menguji hipotesis melainkan hanya mendeskripsikan informasi apa adanya sesuai dengan yang diteliti. Hasil penelitian ini menunjukkan bahwa dengan komoditas kelapa sawit yang merupakan komoditas potensial di Kabupaten Seluma dapat menyerap tenaga kerja dengan data periode 2006-2011 secara umum mengalami peningkatan hal ini juga didukung oleh penjelasan dari Dinas/ Instansi terkait dan anggota kelompok tani di Kabupaten Seluma. Dengan komoditas kelapa sawit kemiskinan di Kabupaten Seluma mengalami penurunan pada penduduk yang bekerja pada komoditas kelapa sawit, hal ini diketahui dari Dinas/ Instansi terkait dengan menyalurkan bantuan sosial kepada penduduk miskin di Kabupaten Seluma mengalami penurunan pada penduduk yang berprofesi sebagai petani komoditas kelapa sawit.
\end{abstract}

\begin{abstract}
Rina Trisna Yanti; The purpose of this study was to determine the role of potential commodities for Employment Expansion in Seluma and To determine the role of potential commodities against Poverty Seluma. This type of research is the study deskriptifkualitatif. This study did not test the hypothesis but only describe the information is in accordance with the study. The results showed that the oil palm which is a potential commodity in Seluma absorb manpower with the data the period 2006-2011 in general has increased it is also supported by an explanation of the Department / Institution related and members of farmer groups in Seluma. With palm oil commodity Seluma poverty decreased among those who work on oil palm, it is known from Department / Institution related to channel social assistance to the poor in Seluma decline in population work as farmers palm oil.
\end{abstract}

\section{Keywords: Potential Commodities, Employment, Poverty Reduction}

\section{PENDAHULUAN}

Pengembangan komoditas potensial daerah diharapkan dapat menciptakan peluang bagi berkembangnya sektor lain yang terkait, baik sebagai input bagi sektor potensial maupun sebagai imbas dari meningkatnya kebutuhan tenaga kerja pada sektor unggulan yang mengalami peningkatan pendapatan. Hal inilah yang memungkinkan pengembangan sektor potensial dilakukan sebagai langkah awal dalam meningkatkan perekonomian daerah.

Pengaruh positif atau negatif dari pertumbuhan penduduk tergantung pada kemampuan sistem perekonomian daerah tersebut dalam menyerap dan secara produktif memanfaatkan pertambahan tenaga kerja. Jumlah tenaga kerja yang lebih besar berarti akan menambah tingkat produksi, sedangkan pertumbuhan penduduk yang lebih besar berarti ukuran pasar domestiknya lebih besar. Meski demikian hal tersebut masih dipertanyakan apakah benar laju 
pertumbuhan penduduk yang cepat benar-benar akan memberikan dampak positif atau negatif dari pembangunan ekonominya.

Jumlah angkatan yang bekerja merupakan gambaran kondisi dari lapangan kerja yang tersedia. Semakin bertambah lapangan kerja yang tersedia maka akan menyebabkan semakin meningkatkan total produksi di suatu wilayah. Hubungan antara pertumbuhan ekonomi dan pembangunan manusia berlangsung melalui penciptaan lapangan kerja. Aspek ini sangat penting karena sesungguhnya penciptaan lapangan kerja merupakan jembatan utama yang mengaitkan antara keduanya.

Pertumbuhan ekonomi Kabupaten Seluma mencapai 5,85 persen per tahun selama periode 2006-2011 yang ditunjukkan oleh kenaikan PDRB rill dari Rp.640.330,46 juta pada tahun 2006 menjadi Rp 9.89384.33 juta pada tahun 2011. Bila disimak perkembangannya per tahun, laju pertumbuhan ekonomi meningkat secara konsisten selama periode 2006-2011.

Pada Tahun 2011 komoditas pertanian dan perkebunan utama yang memiliki keunggulan komparatif yaitu komoditas Kelapa Sawit sebagaimana ditunjukan dengan produksinya 96.307,00 Ton, Karet 36.005,65Ton, Kopi 48.172,00 Ton dan Kelapa 9.032,70 Ton, yang merupakan keunggulan Kabupaten Seluma dengan daerah lainya di Provinsi Bengkulu dan Indonesia. Sedangkan komoditas utama tanaman pangan holtikultura yaitu Padi dengan produksi 67.411 Ton, Jagung dengan produksi 6.562 Ton, Ubi Kayu produksi 1,588 Ton.

Berdasarkan Penelitian Badan Penelitian dan Pengembangan (Balitbang) Provinsi Bengkulu Tahun 2011 dengan menggunakan analisis LQ maka dapat diketahui beberapa komoditas potensial di Kabupaten Seluma didominasi oleh sektor pertanian sub sektor Tanaman Pangan, Holtikultura, Perkebunan, Perikanan dan Peternakan dengan hasil produksi yang cukup menjanjikan keberlangsungan dimasa yang akan datang. Komoditas Kelapa Sawit merupakan komoditas potensial yang menjadi primadona bagi masyarakat Kabupaten Seluma. Dengan komoditas Kelapa Sawit yang merupakan komoditas potensial di Kabupaten Seluma maka diharapkan dapat membuka kesempatan kerja masyarakat Kabupaten Seluma.

Berdasarkan perbandingan sektor pertanian dan sektor bukan pertanian, pilihan bekerja di sektor pertanian masih mendominasi pasar kerja di Kabupaten Seluma, yaitu sebesar $77,06 \%$ pada tahun 2009, sedangkan sektor bukan pertanian sebesar 21,72\%. Untuk provinsi Bengkulu pada tahun 2009 pilihan bekerja pada sektor pertanian sebesar 73,40 \% dan pilihan bekerja pada sektor bukan pertanian sebesar $25,12 \%$.

Dari sektor pertanian, sub sektor perkebunan dengan komoditas kelapa sawit adalah merupakan komoditas potensial di Kabupaten Seluma berdasarkan hasil penelitian Badan Penelitian dan Pengembangan Provinsi Bengkulu dengan menggunakan Location Quation (LQ). Diikuti oleh komoditas karet di posisi kedua, kopi di posisi ke tiga dan kelapa diposisi ke empat.

Tingkat kemiskinan di Kabupaten Seluma dari tahun ke tahun terus terjadi penurunan meskipun tidak terlalu drastis setiap tahunnya. Pada tahun 2009, jumlah penduduk miskin di Kabupaten Seluma sebesar 9,25 \%, angka ini turun dari tahun sebelumnya yaitu sebesar 9,71\%. Jika dibandingkan dengan daerah lain di Propinsi Bengkulu, Kabupaten Seluma menempati urutan ke 2 terbesar setelah Kabupaten Kaur, dan lebih tinggi dari rata-rata kemiskinan propinsi Bengkulu yaitu 8,55 \%.

Kerangka ekonomi yang dibangun atas potensi daerah memungkinkan perekonomian kokoh dan lebih tahan lama dalam menghadapi gejolak ekonomi. Penting diketahui dan diidentifikasi komoditas yang memiliki potensi besar dalam pembangunan ekonomi. Salah satu upaya peningkatan perekonomian rakyat dilakukan dengan mengembangkan produk-produk unggulan, agar dapat membangun struktur ekonomi masyarakat yang tangguh sehingga terhindar dari kemiskinan. Suatu sektor dikatakan berpotensi apabila menjadi basis atau unggulan dalam pembangunan daerah

\section{TINJAUAN LITERATUR Pertumbuhan Ekonomi}

Menurut Arsyad (2004) Pembangunan ekonomi daerah adalah suatu proses dimana pemerintah daerah dan masyarakatnya mengelola sumber daya yang ada dan membentuk suatu 
pola kemitraan antara pemerintah daerah dengan sektor swasta untuk menciptakan lapangan kerja baru dan merangsang kegiatan ekonomi atau pertumbuhan ekonomi dalam wilayah tersebut.

Soepono, (2001) menggambarkan pentingnya ekspor sebagai berikut: pasar ekspor dipandang sebagai penggerak perekonomian lokal. Bila kesempatan kerja yang melayani pasar ini naik atau turun, kesempatan kerja yang melayani pasar lokal juga naik turun. Bila pabrik (ekspor) tutup, padagang eceran (lokal) merasakan dampaknya karena para pekerja pabrik yang diberhentikan tidak memiliki uang untuk dibelanjakan. Karena peranan penggerak utama itu, kesempatan kerja ekspor dipandang sebagai "dasar" (basic atau basis) kesempatan kerja yang melayani pasar lokal dipandang menyesuaikan atau adaptif dan diberi istilah "non dasar" (non basic).

Menurut Hoover and Giarratani (1981), beberapa aktivitas ekonomi dalam suatu wilayah secara khusus merupakan aktifitas basis ekonomi dimana didalam arti pertumbuhannya memimpin dan menentukan perkembangan wilayah secara keseluruhan dan aktifitas lainnya merupakan aktivitas non basis. Dengan demikian perekonomian wilayah dibagi menjadi dua bagian yaitu aktifitas basis dan aktifitas non basis.

\section{Konsep Komoditas Potensial}

Pada lingkup kabupaten / kota, komoditas unggulan kabupaten diharapkan memenuhi kriteria sebagai berikut: 1) mengacu kriteria komoditas unggalan nasional, 2) memiliki nilai eknomi yang tinggi di kabupaten, 3) mencukupi kebutuhan sendiri dan mampu mensuplai daerah lain/ekspor, 4) memiliki pasar yang prospektif dan merupakan komoditas yang berdaya saing tinggi, 5) memiliki potensi untuk ditingkatkan nilai tambahnya dalam agroindustri, dan 6) dapat dibudidayakn secara luas diwilayah kabupaten.

Komoditas unggulan yang ditentukan berdasarkan keunggulan komparatif dan kompetitif pada suatu wilayah adalah komoditas yang tergantung pada besarnya nilai data produksi dan luas tananm suatu komoditas. Akibatnya, komoditas yang telah lama menjadikomoditas spesifik daerah tersisihkan. Padahal komoditas komoditas tersebut, karena sejak lama dikenal sebagai komoditas spesifik tinggi bila diusahakan dengan baik. Komodita yang dapat dimasukan sebagai komoditas spesifik lokasi dicirikan dengan sulitya komoditas tersebut diusahakan di tempat lain. Hal ini menunjukan adanya hubungan khusus (spesifik) antara konoditas tersebut dengan wilayah dimana komoditas tersebut diusahakan

Menurut Soeparmoko (2002) Pengembangan potensi ekonomi suatu daerah adalah kemampuan ekonomi yang ada di daerah yang mungkin dan layak dikembangkan sehingga akan terus berkembang menjadi sumber penghidupan rakyat setempat bahkan dapat menolong perekonomian daerah secara keseluruhan untuk berkembang dengan sendirinya dan berkesinambungan.

Menurut Bachrin (2003) Dalam pengembanganya, komoditas tersebut secara bertahap akan menurun dan tidak memiliki nilai ekonomis khusus lagi serta pada akhirnya akan punah. Pengembangan komoditas spesifik setiap daerah tersebut menjadi tempat wisata dengan sarana dan prasarana yang memadai.

\section{Pertumbuhan Ekonomi dengan Perluasan Kesempatan Kerja}

Penciptaan lapangan pekerjaan merupakan cita-cita setiap pemerintahan yang bertanggungjawab dalam rangka mewujudkan kesejahteraan bagi rakyatnya. Proses penciptaan lapangan pekerjaan sangat berhubungan dengan pertumbuhan ekonomi. Semakin tinggi angka pertumbuhan ekonomi maka semakin marak kegiatan perekonomian yang berarti semakin banyak pula tenaga kerja yang diperlukan untuk mengerakkan roda perekonomian.

Keynes mengungkapkan bahwa kesempatan kerja akan meningkat dan upah juga akan bergerak naik selama tingkat upah yang berlaku dinilai lebih rendah oleh para pengusaha dari pada nilai marginal produk, setelah dikurangi dengan preferensi waktu-waktu sejalan dengan peningkatan sedikit demi sedikit yang dapat diharapkan melalui penggunaan tenaga kerja. 
Dilain pihak, kehilangan kesempatan kerja akan terjadi atau meningkat selama orang menilai bahwa nilai marginal produk yang didapat melalui swasembada, ataupun nilai kepuasan dari kegiatan waktu senggangnya (leisure), lebih tinggi dari upah yang mencerminkan produktivitas marginal jasa/tenaganya.

Menurut Gray (1992), tujuan penciptaan kesempatan kerja berkaitan erat dengan pertimbangan pemerataan pendapatan, mengingat bagian terbesar kelompok penduduk yang tergolong penganggur sekaligus merupakan golongan yang berpenghasilan rendah. Dan terdapat golongan penganggur terdidik yang hidup dari bantuan keluarga sambil menunggu kesempatan kerja dengan tingkat upah yang memenuhi harapannya, biasanya kesempatan kerja di sektor pemerintah.

Manurung (2001) menyatakan bahwa pada negara berkembang, Tenaga kerja (KL) masih merupakan faktor produksi yang sangat dominan. Penambahan tenaga kerja umumnya sangat berpengaruh terhadap peningkatan output. Yang menjadi persoalan adalah sampai berapa banyak penambahan tenaga kerja yang akan meningkatkan output. Hal ini tergantung dari seberapa cepat terjadinya The Law Diminishing Return (TDLR), sedangkan cepat lambatnya proses TDLR sangat ditentukan oleh kualitas sumber daya manusia dan keterkaitan dengan kemajuan teknologi (T) produksi. Selama sinergi antara TK dan teknologi maka penambahan TK akan memacu pertumbuhan ekonomi, dengan demikian dapat dikatakan pada saat terjadi pertumbuhan ekonomi di sisi lain juga akan terjadi penyerapan tenaga kerja.

\section{Pertumbuhan Ekonomi dengan Kemiskinan}

Badan Pusat Statistik (BPS), pengukuran kemiskinan yang dilakukan setiap tahun selalu konsisten sejak tahun 1984 hingga kini dengan menggunakan konsep kemampuan memenuhi kebutuhan dasar (basic needs approach). Dengan pendekatan ini, kemiskinan dipandang sebagai ketidakmampuan dari sisi ekonomi untuk memenuhi kebutuhan dasar makanan dan bukan makanan yang diukur dari sisi pengeluaran. Menurut pendekatan ini, penduduk miskin adalah penduduk yang memiliki rata-rata pengeluaran per kapita per bulan dibawah garis kemiskinan (GK). Secara teknis GK dibangun dari dua komponen yaitu Garis Kemiskinan Makanan (GKM) dan Garis Kemiskinan Non-makanan (GKNM). GKM merupakan nilai pengeluaran kebutuhan minimum makanan yang disetarakan dengan 2.100 kilo kalori per kapita per hari; sedangkan GKNM merupakan kebutuhan minimum untuk perumahan, sandang, pendidikan dan kesehatan.

Sedangkan upaya penanggulangan kemiskinan menurut Undang Undang Nomor 25 Tahun 2000 tentang Propenas ditempuh melalui dua strategi utama. Pertama, melindungi keluarga dan kelompok masyarakat yang mengalami kemiskinan sementara. Kedua, membantu masyarakat yang mengalami kemiskinan kronis dengan memberdayakan dan mencegah terjadinya kemiskinan baru. Strategi tersebut selanjutnya dituangkan dalam tiga program yang langsung diarahkan pada penduduk miskin yaitu: 1) Penyediaan Kebutuhan Pokok; 2) Pengembangan Sistem Jaminan Sosial; dan 3) Pengembangan Budaya Usaha Masyarakat Miskin. Kebijakan tersebut menurut Remi dan Herijanto (2002:29) didasari kebutuhan untuk menutupi penurunan daya beli penduduk akibat krisis ekonomi. 


\section{KERANGKA ANALISIS}

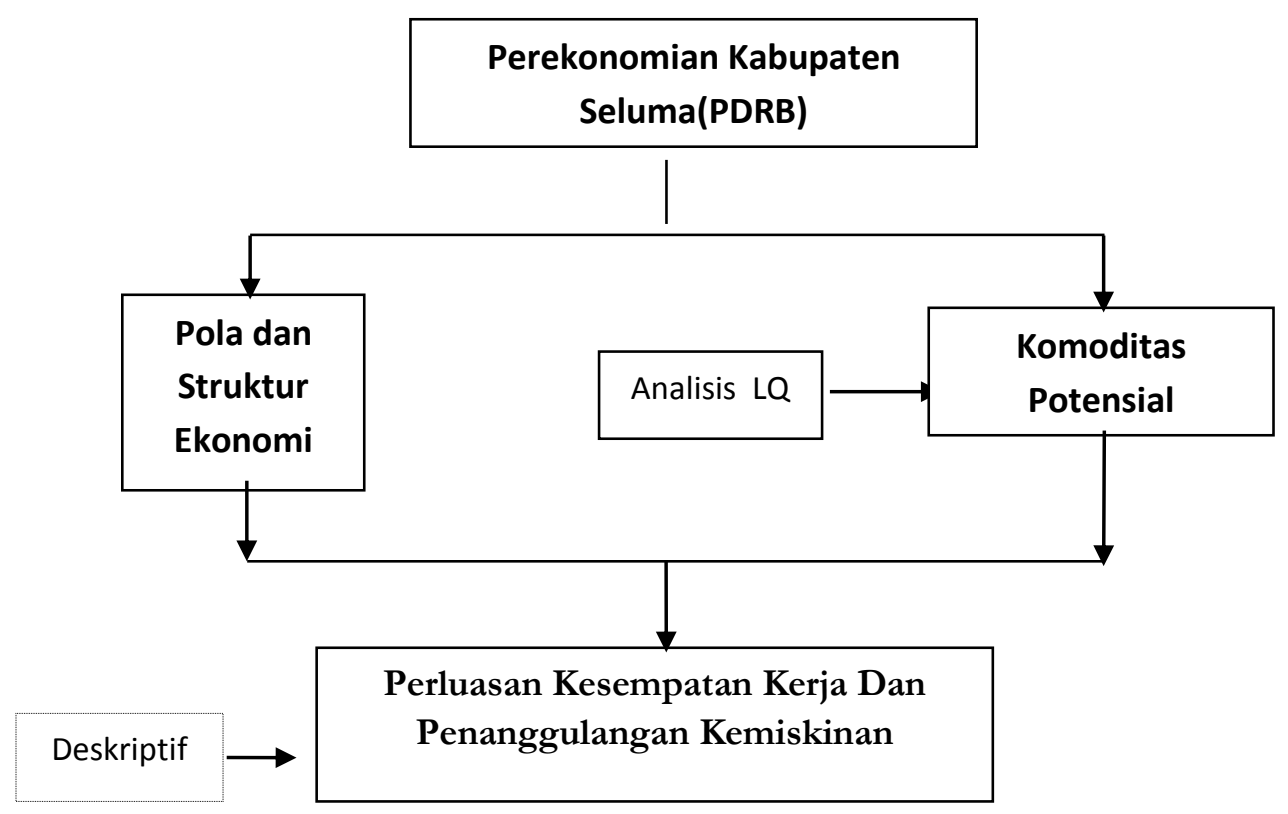

Gambar 1. Kerangka Analisis

\section{HASIL PENELITIAN DAN PEMBAHASAN Peran Komodias Potensial terhadap Kesempatan Kerja}

Produksi kelapa sawit dari periode 2006-2011 pada umumnya meningkat, hanya terjadi penurunan jumlah produksi kelapa sawit pada tahun tahun 2009 hal ini dikarenakan adanya peremajaan perkebuanan besar swasta di kabupaten Seluma. Pada tahun 2006 produksi kelapa sawit sebesar $163.762,25$ ton dengan luas lahan seluas 25.226 ha jumlah tenaga kerja yang terserap sebanyak 9.770 jiwa dengan produktivitas kelapa sawit sebesar 6,482 kg/ha.

Penurunan jumlah produksi kelapa sawit pada tahun 2009 menjadi 81.449,15 ton atau selisih 144.099,1 ton dari tahun sebelumnya sedangkan luas lahan perkebunan meningkat menjadi 25.451 ha dari tahun sebelumnya menurut para kelaompok tani disebabkan oleh adanya peremajaan perkebunan besar swasta di Kabupaten seluma dan sulitnya dalam mendapatkan pupuk bersubsidi pada perkebunan rakyat, hal ini bukan dikarenakan pasokan yang berkurang kepada kelompok tani, melainkan ada oknum tertentu yang menjual pupuk bersubsidi secara bebas, sehingga petani kelapa sawit yang tergabung dalam kelompok tani kurang mendapatkan pasokan pupuk bersubsidi dan harga jual pupuk tidak subsidi sangat tinggi dipasaran yang akhirnya berdampak pada menurunya kesuburan kelapa sawit sehingga berkurangnya hasil produksi. Pada tahun 2011 jumlah produksi kelapa sawit kembali mengalami peningkatan menjadi $96.307,00$ Ton dan dikuti dengan peningkatan luas lahan perkebunan Kelapa Sawit, hal ini disebabkan semakin menjamurnya perkebunan rakyat, dan adanya perluasan lahan perkebunan kelapa sawit swasta yang diikuti dengan pembangunan pabrik pengolahan buah kelapa sawit (pabrik CPO di Kabupaten Seluma), sedangkan jumlah penyerapan tenaga kerja menjadi 16.814 jiwa

Pada Tabel 1. dapat dilihat bagaimana pergerakan jumlah penyerapan tenaga kerja pada perkebunan kelapa sawit di Kabupaten Seluma berdasarkan jumlah produksi dan produktivitas kelapa sawit periode tahun 2006-2011. Jumlah tenaga kerja yang terserap meliputi Petani, Pekerja Hasil Produksi (pemanen, pekerja jasa angkut hasil produksi) yang terdapat pada perkebunan rakyat. Pada tabel tersebut juga terlihat produktivitas perkebunan kelapa sawit mengalami penurunan hal ini dikarekan peremajaan perkebunan swasta besar di kabupaten Seluma. 
Tabel 1 :Produksi , Luas Lahan, Produktivitas dan Jumlah Tenaga Kerja Yang Terserap Pada Perkebunan Kelapa Sawit Di Kabupaten Bengkulu Utara Periode 2006-2011.

\begin{tabular}{ccccc}
\hline Tahun & Produksi (Ton) & Luas Lahan (Ha) & $\begin{array}{c}\text { Produktivitas } \\
\text { (Ton/Ha) }\end{array}$ & $\begin{array}{c}\text { Jumlah Tenga } \\
\text { Kerja }\end{array}$ \\
\hline $\mathbf{2 0 0 6}$ & $163.762,25$ & 15.374 & 10,651 & 11.770 \\
$\mathbf{2 0 0 7}$ & $329.985,30$ & 25.391 & 12,996 & 14.905 \\
$\mathbf{2 0 0 8}$ & $225.548,25$ & 17.892 & 12,606 & 13.431 \\
$\mathbf{2 0 0 9}$ & $81.449,15$ & 25.451 & 3,200 & 15.256 \\
$\mathbf{2 0 1 0}$ & $92.438,79$ & 42.828 & 2,158 & 17.170 \\
$\mathbf{2 0 1 1}$ & $96.307,00$ & 48.808 & 1,973 & 16.814 \\
\hline
\end{tabular}

Sumber : Dinas Kehutanan dan Perkebunan Kabupaten Seluma Tahun 2012

Menurut Kepala Dinas Kehutanan dan Perkebunan Kabupaten Seluma peningkatan luas lahan perkebunan kelapa sawit pada tahun 2011 dikarenakan adanya perluasan perbebunan besar swasta di Kabupaten Seluma yang didukung oleh pembangunan pabrik CPO di Kabupaten seluma. Selain itu untuk mendukung perkebunan kelapa sawit pemerintah juga melakukan sosialisasi kepada petani kelapa sawit tentang pengelolaan dan pemupukan kelapa sawit yang baik serta Pemerintah Kabupaten Seluma melalui Dinas Kehutanan dan Perkebunan melakukan program pengembangan revitalisasi perkebunan yang diarahkan pada wilayah-wilayah sentral produksi perkebunan. Disamping itu perlu dikembangkan pola pengembangan perkebunan terpadu dengan peternakan seperti integrasi kelapa sawit dengan sapi.

Sedangkan penyebab penurunan jumlah tenaga kerja yang terserap pada perkebunan kelapa sawit pada tahun 2011 dikarenakan harga tandan buah segar (TBS) menurun hingga Rp.800,-/Kg. Hal ini yang menyebabkan sebagian penduduk Kabupaten Seluma beralih bercocok tanaman holtikultura, sedangkan para pemilik perkebunan kelapa sawit sebagian besar menjual TBS langsung ke tengkulak dengan harga yang lebih rendah dari harga di pabrik. Menurut pernyataan dari anggota Kelompok Tani Gepoktan Seluma apabila mereka memaksakan untuk memanen kelapa sawit maka biaya akan seamakin besar dan tidak sebanding dengan hasil yang diterima dari penjualan TBS yang harganya merosot turun.

\section{Peran Komoditas Potensial Terhadap Penanggulangan Kemiskinan.}

Tingkat kemiskinan di Kabupaten Seluma pada umumnya mengalami penurunan dalam periode 2006-2011, hal ini dikarenakan program atau kegiatan yang dikembangkan dari berbagai sektor ekonomi. Sektor pertanian merupakan sektor yang paling besar peranannya dalam penanggulangan kemiskinan. Dimana masyarakat yang bekerja pada sektor pertanian khusus sub sektor tanaman perkebunan dapat meningkatkan pendapatannya dari hasil produksi perkebunan yang dikelola.

Menurut Kasi Bimbingan Keluarga Miskin pada Dinas Sosial Kabupaten SEluma, beliau mengatakan bahwa pada tahun 201270 \% dari penduduk miskin yang ada di Kabupaten Seluma bermata pencaharian pada sektor pertanian terutama pada perkebunan kelapa sawit dan karet serta sektor pertanian tanaman pangan. Beliau juga menyatakan bahwa melalui penerapan Rencana Pembangunan Jangka Menengah Daerah (RPJMD) guna penanggulangan kemiskinan diterapkan dalam program yang dilaksanakan oleh Pemerintah Kabupaten Seluma.

Melalui Dinas Sosial Kabupaten Seluma pemerintah memberikan santunan atau bantuan kepada masyarakat miskin, dengan kegiatan ini dapat terdeteksi masyarakat miskin yang berprofesi sebagai petani kelapa sawit periode tahun 2006-2011 mengalami penurunan. Pada tahun tahun 2010 persentase penduduk miskin yang bekerja pada perkebunan rakyat sebesar 94\% dan pada tahun 2011 menurun menjadi 92\%, hal ini dikarenakan berkuranganya jumlah keluarga penerima santunan atau bantuan dengan indikator bagi penduduk miskin yang berprofesi sebagai petani kelapa sawit dengan penghasilan dibawah Rp. 600.000,-/ bulan. Penyebab masih adanya sebagian keluarga miskin yang berprofesi sebagai petani kelapa sawit dikarenakan kurangnya pengetahuan petani komoditas kelapa sawit dalam pemilihan bibit pada awal tanam, mereka tidak menggunakan bibit unggul, sehingga berpengaruh terhadap 
produksi kelapa sawit yang tidak maksimal yang akhirnya berdampak pada pendapatan yang kecil, sehingga tidak dapat memenuhi kebutuhan rata-rata dalam keluarga.

Menurut anggota 1 kelompok tani Gepoktan Kabupaten Seluma yang yang memiliki perkebunan kelapa sawit seluas 5 Ha dan telah siap panen, dengan rata-rata produksi 8 Ton dalam satu bulan dan rata-rata pendapatan dalam sebulan dari hasil berkebun kelapa sawit sebesar Rp. 4.000.000,-, beliau menyatakan bahwa dengan penghasilan dari berkebun kelapa sawit dapat meningkatkan ekonomi keluarganya yang beranggotankan Bapak dan Ibu serta 2 orang anak. Beliau juga dapat menyekolahkan kedua anaknya hingga keperguruan tinggi, hanya saja terkendala pada harga pupuk yang relatif mahal dan sulit didapat yang menjadi kekhawatiran beliau akan menurunnya prokdusi dari perkebunan kelapa sawit.

Beliau berkebun kelapa sawit diawali dengan lahan keluarga yang tidak di kelola, dengan mengajukan pinjaman ke Bank BRI beliau mulai mengelola lahan keluarga tersebut dengan membeli bibit dari warga yang membudidayakan bibit kelapa sawit. Dengan berkebun kelapa sawit beliau yang awalnya tinggal bersama orang tuanya, maka sekarang dapat membangun rumah sendiri dengan kriteria beton permanen. Dengan 10 tahun umur tanam perkebunan kelapa sawitnya, beliau tidak lagi mendapatkan bantuan/ santunan dari Pemerintah karena dengan pengahasilannya sudah cukup dan beliau tidak tergolong sebagai penduduk miskin. Dewasa ini dengan harga TBS yang menurun dirasa beliau tidak terlalu mengganggu perekonomian keluarganya.

Hal serupa juga dialami oleh anggota 2 kelompok tani Gepoktan Kabupaten Seluma yang juga menggantungkan perekonomian keluarganya dengan 3 orang anak untuk keberlangsungan hidup dan pendidikan anaknya. Beliau memiliki luas lahan perkebunan kelapa sawit seluas 4 Ha. Dalam satu bulan kebun kelapa sawitnya dapat menghasilkan produksi rata-rata sebesar 9 ton dan rata-rata pendapatan dalam sebulan dari hasil berkebun kelapa sawit sebesar Rp. 4.500.000,-, lebih banyak dibandingkan oleh anggota 1 walaupun luas lahan berbeda. Hal ini dikarenakan Anggota 2 menggunakan bibit kelapa sawit yang berasal dari PT. Puding Mas yang notabene merupakan Perusahaan yang menjual bibit unggul, sehingga rata-rata hasil produksi kebun kelapa sawitnya lebih banyak, sedangkan anggota 2 mendapatkan bibir dari temannya yang membudidayakan bibit kelapa sawit. Produksi kelapa sawit beliau sedang meningkat dengan umur tanam 6 tahun yang merupakan waktu dimana produksi kelapa sawit terbaik. Dengan hasil yang diterima dari berkebun kelapa sawit dapat merubah kehidupan beliau menjadi lebih baik, hal ini dapat dilihat dengan rumah tinggal beliau yang layak dengan konstruksi beton permanen, jika dibandingkan dahulu beliau yang hanya bekerja sebagai buruh pasar. Beliau memperoleh lahan dari pembelian dengan pengajuan pinjaman dana ke Bank Perkreditan Rakyat yang pada saat itu bunga pinjaman relatif kecil.

\section{Simpulan}

1. Peran komoditas potensial di Kabupaten Seluma berupa komoditi kelapa sawit berperan sangat baik dalam perluasan kesempatan kerja bagi penduduk Kabupaten Seluma. Hal ini dapat dilihat secara umum penyerapan tenaga kerja yang bekerja pada perkebunan komoditas kelapa sawit di Kabupaten Seluma mengalami peningkatan pada periode 20062011.

2. Selanjutnya peran komoditas potensial di Kabupaten Seluma yaitu komoditas kelapa sawit dalam penanggulangan kemiskinan juga berperan baik. Dikatakan berperan baik karena para petani yang berkebun kelapa sawit dapat memenuhi kebutuhan keluarganya dengan indikator tempat tinggal yang layak dan sarana pendidikan bagi keluarganya serta berkurangnya penerima bantuan atau santunan untuk kategori penduduk yang berprofesi sebagai petani kelapa sawit.

\section{Saran}

1. Untuk Pemerintah Kabupaten Seluma agar dapat memberikan pelatihan tentang berkebun kelapa sawit kepada para petani agar jumlah produksi kelapa sawit yang besar, yang 
akhirnya berdampak pada pengahsilan yang besar pula bagi masyarakat, sehingga jumlah pengangguran dapat turun seiring dengan tertariknya penduduk untuk bekerja pada komoditas kelapa sawit.

2. Penanggulangan kemiskinan menjadi pekerjaan rumah yang selalu dicanangkan pada setiap tahunnya dengan program-program yang baik. Melalui Dinas Pertanian subsudi pupuk sudah diterapkan hanya saja untuk para kelompok tani saja. Sebaiknya perlu dilakukan pengawasan dalam pemberian pupuk bersubsidi agar berkurangnya penjualan pupuk bersubsidi yang tidak tepat sasaran.

\section{DAFTAR PUSTAKA}

Anonim. 2005-2010. Badan Pusat Statistik Provinsi Bengkulu. Bengkulu Dalam Angka, Bengkulu. 2005-2010. Badan Pusat Statistik Kabupaten Bengkulu Utara. Bengkulu Utara Dalam Angka, Bengkulu Utara.

2005-2010. Badan Pusat Statistik Provinsi Bengkulu. Statistik Perkebunan, Bengkulu.

Apriyani, 2009. Metode Penelitian Kualitatif. Sinar Terang. Surabaya

Arsyad, Lincolin. 1999. Ekonomi Pembangunan, Edisi 3 Bagian. STIE YKPN Yogyakarta. 2004. Ekonomi Pembangunan, Edisi 3 Bagian. STIE YKPN. Yogyakarta.

Asaddin dan Mansoer. 2001. Petumbuhan Ekonomi dan Kesempatan Kerja: Terapan Model Kebijakan Prioritas Sektoral untuk Kalimantan Timur. Jurnal Riset Akutansi, Manajemen Ekonomi Vol 1. No. 1, Februari 2001 Hal. 89-103.

Aubert, C and Zhu Xigang. 2002. The Changing Role Of Soybean in China's Food System: A Study in its Production, Processing, Consumption and Trade. Eu-China Joint Resaerch Project.

Boediono. 1981. Teori Pertumbuhan Ekonomi. BPFE T Yogyakarta Mada, Edisi Pertama Yogyakarta, Tidak Dipublikasikan.

Bendavid, Avrom. 1991. Regional and Local Economic Analisys for Practioners, Fourth Edition, New York.

Blakely, Edward J. 1983. Planning Local Economic Development, Theory and Practice, Second Edition. New Delhi.

CGPRT. 1985. The Soybean Commodity System In Indonesia. Bogor Researchn Institute for Food Crops. Central Research Institute For Food Crops. ESCAP CGPRT Centre.

Debraj. 1998. Development Economics. Princeton University press, New Jersey. Dornbusch, Rudiger dan Stanley Fischer. 1990. Ekonomi Makro, Edisi Keempat, Penerbit Erlangga Jakarta, Jakarta.

Elmi, Bachrul. 2004. Studi Pembiayaan Pembangunan Perkotaan (Urban Development Finance) Kota Prabumulih, Kajian Ekonomi dan Keuangan, Vol.8, No. 1. Maret.

Hoover, Edgar, Mand Frank Giarrantani. 1981. An Introduction to Regional Economics. Third Edition. New York: Alfred A.Knopf, Inc.

Manurung, M dan Rharja, P. 2001. Teori Ekonomi Makro. Lembaga Penerbit Fakultas Ekonomi Universitas Indonesia. 
Mikkelsen, Britha. 2003. Metode Penelitian Partisipatoris dan Upaya-Upaya Pemberdayaan. Terjemah: Matheos Nalle Jakarta: Yayasan Obor Indonesia.

Mubyarto, 1989. Pengantar Ekonomi Pertanian, Teori, Masalah dan Kebijaksanaan, UPP AMP YKPN, Yogyakarta.

Nugroho, Iwan dan Rokhmin Dahuri. 2004. Pembangunan Wilayah- Perspektif Ekonomi, Sosial dan Lingkungan. Jakarta: Pustaka LP3ES.

Richardson, Harry. W. 1977. Dasar-Dasar Ilmu Ekonomi Regional, (Terjemahan: Paul Sitohang), LPFE-UI. Jakarta.

Rohadi, Rohendi T. 1993. Ekspresi Seni Orang Miskin: Adaptasi Simbolik Terhadap Kemiskinan, UI Press, Jakarta.

Sabana, Choliq. 2007. Analalisis Pengembangan Kota Pekalongan Sebagai Salah Sotensi Ekonomi Satu Kawasan Andalan di Jawa Tengah, Tesis. Program Pasca Sarjana UNDIP. Semarang.

Soegijoko, Budi Tjahjati S. dan BS Kusbiantoro (ed). 1997. Bunga Rampai Perencanaan Pembangunan di Indonesia. Bandung: Yayasan Soegijanto Soegijoko.

Soekarni. 2002. Ekonomi Pembangunan, YKPN, Yogyakarta.

Soeparmoko. 2002. Ekonomi publik Untuk Keuangan dan Pembangunan Daerah. Edisi Pertama. Andi. Yogyakarta.

Soepono, Prasetyo. 1993. Teori Pertumbuhan Berbasis Ekonomi (Ekspor) Posisi dan Sumbanganya bagi Perbendaharaan Alat-alat Analisis Regional. Jurnal Ekonomi dan Bisnis Indonesia. Vol. 16 No. 1.

Sukirno, Sadono. 1985. Ekonomi Pembangunan, Proses, Masalah dan Dasar Kebijakan, LPFE UI. Jakarta.

Sulistriyanto. 2004. Aplikasi Analisis Shift Share Esteban-Marquilas pada Sektor Pertanian di Kabupaten Boyolali. Universitas Negeri Sebelas Maret, Surakarta.

Tambunan, TH. 2001. Perekonomian Ekonomi dan Ketimpangan Regional Wilayah Indonesia Bagian Barat, LP3S, Jakarta.

Tim Kajian Kemiskinan Parsitipatoris. 2004. Memahami Suara Orang Miskin. Smeru Newsletter, No.11: Juli-September 2004. 